\title{
Effect of Somatostatin Analogs on Prostate Volume
}

\section{Somatostatin Analoglarının Prostat Volümü Üzerine Etkisi}

\author{
Osman KOSTEK ๑, Muhammet Bekir HACIOGLU ๑
}

Ethics Committee Approval: This study approved by the Trakya University Clinical Studies Ethic Committee, 01 October, 2018, 16/14.

Conflict of interest: The authors declare that they have no conflict of interest. Funding: None.

Informed Consent: Not Applicable.
Cite as: Kostek O, Hacioglu MB. Effect of Somatostatin Analogs on Prostate Volume. Medeniyet Med J. 2019;34:176-81.

\begin{abstract}
Objective: Somatostatin is an acidic peptide that has mainly inhibitory function in the endocrine system. We aimed to evaluate whether there is a dimensional change in prostate in patients with gastrointestinal neuroendocrine tumors (NET) treated with somatostatin analogues.

Methods: Most of the patients were given $30 \mathrm{mg} I M$ long-acting octreotide acetate at 4-week intervals for the treatment of neuroendocrine tumor. Only 1 patient received $120 \mathrm{mg}$ of another long-acting somatostatin analog subcutaneously every 4 weeks. Baseline and follow-up CT studies of the patients who were under treatment with somatostatin analogs were performed. Results: A total of 15 NET patients who received somatostatin analogs were analyzed. Thirteen (86.6\%) patients had reduced prostate volume after somatostatin analog use. Median reduction in the volume of prostate was 5.66 (1.97-9.60) cc with somatostatin analog use (median treatment time was 3.2, 2.8-8.6 months). Median overall survival was 34.8 months $(95 \% \mathrm{CI}$ 13.8-55.9) in all patients. It was 36.1 months (95\% CI 9.5-62.7) in patients with reduced prostate volume and 21.7 (95\% Cl 6.9-36.5) months in those whose prostate volumes remained unchanged $(p=0.14)$.

Conclusions: interestingly, Somatostatin analogue therapy has decreased prostate volumes in NET patients. Potential therapeutic role of somatostatin analogs in the treatment of benign prostat hyperplasia patients might be evaluated in prospective studies.
\end{abstract}

Keywords: Somatostatin analog, prostate gland, volume, neuroendocrine tumor

öz

Amaç: Somatostatin, endokrin sistem üzerinde etkili ve majör görevi inhibisyon olan asidik bir peptittir. Somatostatin analogları ile tedavi edilen gastrointestinal nöroendokrin tümörlü (NET) hastalarda prostatta boyutsal bir değişimin olup olmadığını değerlendirmeyi amaçladık.

Yöntem: Hastaların çoğuna nöroendokrin tümör nedenyle, intramusküler olarak 4 hafta arayla 30 mg uzun etkili oktreotid asetat verildi. Yalnızca 1 hasta, her 4 haftada bir subkutan 120 mg başka uzun etkili somatostatin diğer bir analog olan lanreotid aldı. Somatostatin analog tedavisi altında bazal ve yanıt değerlendirme sürecinde çekilen bilgisayarlı tomografi görüntüleri ile prostat volüm değerlendirilmesi yapıldı.

Bulgular: Somatostatin analoğu alan toplam 15 NET hastası analiz edildi. On üç $(\% 86,6)$ hastada somatostatin analog kullanımından sonra prostat hacmi azalmış olarak saptandı. Somatostatin analog kullanımı ile ortanca azalmış hacim 5,66 (1,97-9,60) cc idi (ortanca tedavi süresi 3,2, 2,88,6 aydı). Tüm hastalarda medyan genel sağ kalım 34,8 ay (\%95 CI 13,8-55,9) idi. Prostat hacmi azalmış hastalarda 36,1 ay (\%95 CI 9,5-62,7) ve prostat hacimleri değişmeden kalanlarda 21,7 (\%95 Cl 6,9-36,5) idi $(p=0,14)$.

Sonuç: NET hastalarında somatostatin analog tedavisi, prostat hacimlerinin düşmesine neden oldu. Prostat hacmi artmış hastalarının tedavisinde somatostatin analoğunun potansiyel terapötik rolü prospektif çalışmalarda değerlendirilebilir.

Anahtar kelimeler: Somatostatin analoğu, prostat bezi, hacim, nöroendokrin tümör
Received: 6.02.2019

Accepted: 23.03 .2019

Online First: 10.06 .2019

Corresponding Author: O. Kostek ORCID: 0000-0002-1901-5603 Trakya University, Department of Medical Oncology, Edirne - Turkey

osmankostek@hotmail.com

M.B. Hacioglu ORCID: 0000-0001-8490-3239 Trakya University, Department of Medical Oncology, Edirne, Turkey 


\section{INTRODUCTION}

Somatostatin (STS) is a hormone with an acidic peptide structure that is secreted by peripheral tissues, central nervous system and organs. It is abundant in the gastrointestinal tract and pancreas where it is produced by paracrine and endocrinelike D cells and by enteric nerves ${ }^{1}$. There are five known subtypes of the STS receptor (designated as 1 to 5 ). It exerts its main action by inhibiting various cells via direct or indirect mechanisms. Direct inhibition involves the activation of STS receptors in tumor cells inducing cell-cycle arrest or apoptosis via activities of MAP kinase and phosphotyrosine phosphatase ${ }^{2}$. As for the indirect mechanism, expression of STS receptors on some blood veins is thought to inhibit tumor angiogenesis and secretion of growth factors ${ }^{3}$. Due to its role in controlling cellular proliferation and differentiation in epithelial tissues via the activation of different intracellular signaling pathways, it is considered as an option in the treatment of neuroendocrine tumors ${ }^{4-7}$. STS and its analogs, lanreotide and octreotide, are highly effective in controlling gastrointestinal NETrelated symptoms.

Normal prostate tissue is consisted of stromal and epithelial components. It contains secretory, basal, urothelial, and neuroendocrine cells. In normal prostate and benign hyperplasia of prostate tissue, STS receptor 2 is localized in the luminal side of the duct and acinar cells, as well as being expressed in stromal cells ${ }^{8}$. Moreover, in a recent study, it was shown that STS receptor 1 levels were over-expressed in patients with prostate cancer'. On the other hand, in vitro studies have demonstrated that somatostatin analogs act as a cytotoxic agent against prostate cancer cells, but this has not been validated with in vivo studies, yet $^{10}$. There is not enough data about the effect of STS analog on normal prostate and benign hyperplasia of prostate. In this study, we aimed to assess whether a dimensional change on the prostate is possible in NET patients who were treated with somatostatin analogs.

\section{MATERIAL and METHODS}

This study approved by the Trakya University Clinical Studies Ethic Committee, 01 October, 2018, $16 / 14$.

\section{Study patients}

This retrospective study carried out on metastatic neuroendocrine tumor patients who were admitted to our medical oncology hospital between years 2007 and 2017. Medical records of 42 patients with metastatic NET, Grade 1 or 2 NET, were screened and 15 of them were found to be eligible These male patients had undergone CT scanning before and after somatostatin analog treatment. All patients had histologically proven Grade 1 or 2 neuroendocrine tumors and liver metastasis as well.

\section{Somatostatin analog treatment}

Majority of the patients were treated with $30 \mathrm{mg}$ IM long-acting octreotide acetate at 4-week intervals. Only 1 patient received $120 \mathrm{mg}$ of another long-acting somatostatin analog subcutaneously every 4 weeks.

\section{CT imaging}

Prostate volume measurements of the study subjects were performed (Aquillon, 64-detector, Toshiba Medical Systems, Tokyo, Japan) using baseline and follow-up CT imaging. The CT imaging parameters were as follows: helical pitch 53; gantry rotation time, $0.5 \mathrm{~s} ; 125 \mathrm{mAs}$; section collimation, $0.5 \mathrm{~mm}$ and $120 \mathrm{kVp}$. Prostate volume calculation with CT was carried out with the ellipsoid formula providing volume estimations based on three dimensional measurements $(0.52 \mathrm{x}$ length $(\mathrm{cm}) \times$ width $(\mathrm{cm}) \times$ height $(\mathrm{cm}))^{11}$. Prostate volumes were evaluated by a radiologist (EY) with 12 years of $\mathrm{CT}$ imaging experience (EY).

\section{Statistical analysis}

Data were reported as mean \pm standard deviation or median, and minimum-maximum in parantheses. Categorical variables were reported as num- 
bers and percentages. Change of prostate volume from baseline was presented by median $\left(25^{\text {th }}-75^{\text {th }}\right.$ interquartile range). Wilcoxon signed-rank test was used to evaluate the change of prostate volume from baseline to subsequent CT imaging. Kaplan-Meier test was used to assess the overall survival. P value below 0.05 was considered as statistically significant.

\section{RESULTS}

\section{Study patients}

A total of 15 NET patients who received somatostatin analog were analyzed. The median age was 56 (28-73) years. Diagnosis of all patients was confirmed with biopsy and $86.7 \%$ of them were documented as Grade 2. In most of them, primary tumor localization was identified as pancreas and all of them had liver metastasis and carcinoid syndrome. ECOG status was between 0 and 1 . Baseline characteristics of study subjects are presented in Table 1.

Table 1. Demographic and clinical characteristics of study subjects.

\begin{tabular}{ll}
\hline Age, years & \\
$\quad$ Median (Interquartile range) & $56(46-66)$ \\
Body Mass Index, kg/m² & $26.7 \pm 3.4$ \\
Primary tumor localization, n (\%) & \\
Pancreas & $7(86.7)$ \\
Stomach & $2(13.3)$ \\
Small intestine & $1(6.7)$ \\
Lung & $2(13.3)$ \\
$\quad$ Unknown & $3(20.0)$ \\
Histological grade, n (\%) & \\
$\quad$ Grade 1 & $2(13.3)$ \\
$\quad$ Grade 2 & $13(86.7)$ \\
Ki-67 (\%) & \\
Median (Interquartile range) & $5(3-10)$ \\
Mitotic rate & \\
Median (minimum-maximum) & $5(3-15)$ \\
\end{tabular}

\section{Change in Prostate volume}

Prostate volumes at baseline and after somatostatin analog treatment are shown in Table 2 . Thirteen $(86.6 \%)$ patients prostate volume had reduced after STS analog use. Median reduced volume was 5.66 (1.97-9.60) cc with somatosta- tin analog use (median treatment time was 3.2, 2.8-8.6 months). In addition, median time between two CT evaluations was 7.9 (3.7-13.7) months. Treatment with STS analog was associated with a significant decrease in prostate volume $(p=0.001$, Table 2, Figure 1).

Table 2. Prostate volume change after somatostatin analog use.

\begin{tabular}{lll}
\hline Baseline volume & $\begin{array}{l}\text { Volume after } \\
\text { somatostatin }\end{array}$ & $\begin{array}{l}\text { Somatostatin use } \\
\text { period (month) }\end{array}$ \\
\hline 55.90 & 55.98 & 2.12 \\
31.60 & 31.62 & 2.12 \\
43.15 & 41.31 & 3.25 \\
18.95 & 16.84 & 5.13 \\
31.68 & 29.23 & 2.66 \\
40.20 & 35.50 & 2.96 \\
44.88 & 39.22 & 2.73 \\
39.96 & 34.04 & 6.12 \\
42.32 & 35.91 & 12.12 \\
47.50 & 39.48 & 10.02 \\
40.32 & 30.60 & 7.13 \\
63.60 & 52.42 & 67.84 \\
61.07 & 49.70 & 61.86 \\
87.42 & 75.90 & 3.09 \\
52.80 & 39.70 & 24.12 \\
& & \\
\hline
\end{tabular}

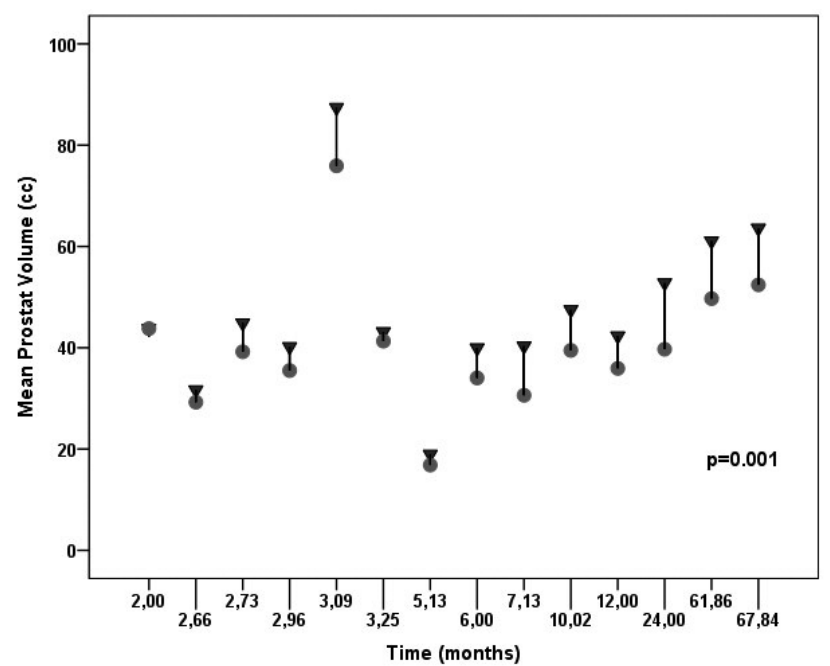

Figure 1. Prostate volume at baseline and after somatostatin analog use.

Median OS was 34.8 months (95\%Cl 13.8-55.9) in all patients. It was 36.1 months $(95 \% \mathrm{Cl} 9.5$ 62.7) in patients with reduced prostate volume and 21.7 (95\% Cl 6.9-36.5) in those whose prostate volumes remained unchanged $(p=0.14)$. 


\section{DISCUSSION}

Normal prostate tissue is largely composed of stromal and epithelial components. While a small part of prostate is made up of neuroendocrine cells that are thought to play a role in growth, differentiation, and secretory functions of the prostate gland. In this study we were able to demonstrate a significant decrease in the prostate volumes of NET patients treated with STS analogs.

Main function of the prostate gland is the production of seminal fluid. The tissue is made up of glandular epithelial and fibromuscular stroma cells. Glandular epithel comprises 3 types of cells: basal, luminal secretory and neuroendocrine. Luminal cells secrete the prostatic fluid, androgenous receptor expression, and prostate specific antigene (PSA). Basal cells are thought to secrete the components of the basal membrane. As for the neuroendocrine cells, their function is not fully understood $^{12}$. Publications are available on the presence of STS receptors in this cell population ${ }^{13}$. STS analogs are associated with an inhibition of the exocrine glands in endocrine system. It is unknown whether anti-secretory action of STS analogs lead to reduction in the size of the prostate. On the other hand, studies on the subject revealed that STS analogs have antineoplastic activity which is manifested by direct expression of STS receptors on tumor cells. Moreover, they inhibit the secretion of hormones and growth factors through expression of receptors by non-tumoral cells, thereby blocking angiogenesis and tumor cell growth ${ }^{14,15}$. There are studies demonstrating that inhibition through somatostatin is possible by way of inhibiting the angiogenic factors with neuroendocrine cells ${ }^{16,17}$. On the other hand, in benign prostatic hyperplasia (BPH) and malignant prostatic tissue STS receptor 2 and STS receptor $4 \mathrm{~m}$ RNA were detected and STS receptor 2-with STS receptor 4-positive mRNA signals were found to be up-regulated in cells subjected to malignant transformation compared with $\mathrm{BPH}$ secretory epithelial cells ${ }^{13}$. In connection with this, STRSmediated signals in tumor and non-tumor cells of the prostate have anti-proliferative effects ${ }^{18}$. Moreover, other studies also demonstrated that the somatostatin activity on cyclin E expression functioned as an androgen receptor co-activator which induce an increase in cyclin-dependent kinase levels by reducing cyclin $\mathrm{E}$ expression and represses G1/S transition during cell division ${ }^{19,20}$. These results suggest that the prostate gland is a potential target for STS receptor 2-and STS receptor 4-specific agonists. The various mechanisms whereby somatostatin affects secretory and neuroendocrine prostate cells have been demonstrated, but further clinical studies are needed to show its clinical effect on BPH or normal prostate tissue. In our study, however, we have demonstrated that in patients treated with somatostatin for neuroendocrine tumors, the increased prostate volume before and after treatment is significantly reduced in connection with the length of time the medicine is used. We have seen that volume loss in prostate gland is not a predictor of median OS. Its prognostic significance, however, could be better explored through studies with a larger number of participants.

$\mathrm{BPH}$ is a benign condition in which an overgrowth of prostate tissue and associated symptoms of the lower urinary tract result from complex changes in the prostate. BPH involves the cellular components of the prostate including the epithelial and stromal cells ${ }^{21}$. Benign prostatic hyperplasia is mostly seen in older men and its underlying etiology has not been fully explored. Inflammation, cellular stress, steroid hormones (estrogen, androgen), growth factors and other contributors are thought to play a part in the development of this disease ${ }^{22}$. Prostate size was measured by transrectal ultrasonography (TRUS) and a volume above $30 \mathrm{ml}$ is considered $\mathrm{BPH}^{23}$. However, enlargement of the prostate gland is considered as a natural part of the "ageing process" to a certain extent (1.7\% per year) and does not necessarily cause lower urinary tract symptoms. On the other 
hand, in prostate volume measurements CT may yield higher values than TRUS ${ }^{11}$. In our study, the median pre-treatment prostate volume was 43.1 $\mathrm{mL}$ (min-max=18.9-87.4) and only in 1 patient the prostate volume was found to be under 30 $\mathrm{mL}$. No study has been conducted yet to show that somatostatin causes a volume decrease in the normal prostate tissue. After somatostatin use, significant volume change was observed. As far as we know, this article is the first to demonstrate significant decrease in volume of $\mathrm{BPH}$ due to somatostatin use. Also, considering the clinical characteristics of a condition as important as BPH, the results of the study suggest that somatostatin might be an alternative potential treatment option especially for patients who suffered from obstructive problems during urination and have complaints of low back pain.

There are some major limitations. Firstly, retrospective study design with the medical records of patients with neuroendocrine tumor brings expected disadvantages in the assessment of BPH-related symptoms before and after treatment with somatostatin analog. Secondly, study population size was small due to the incidence of neuroendocrine tumor and male gender evaluation. Prostate volume measurements were performed twice: at baseline and follow-up. All measurements were made based on CT findings, but it would have been better if prostate volumes were confirmed with TRUS. There was no histopathologic confirmation after use of somatostatin analogs. Furthermore, due to retrospective study design, suboptimal and incomplete data about the toxicity profiles could be gathered. Although the presence of these limitations, as an outstanding strength of the study we conclude that increased prostate volume could be reduced with STS analogs. As a result, our conviction is that STS analogs may be an option for the treatment of patients with BPH-related symptoms, such as lower urinary tract or compression-related disorders.

\section{CONCLUSION}

Somatostatin analog treatment in NET patients has remarkably resulted in decreased prostate volumes. Long-term somatostatin analog use might reduce the enlarged prostate volume. Potential therapeutic role of somatostatin analogs on enlarged prostate volume should be clarified with prospective studies.

Acknowledgement: Authors would like to thank Erdem Yilmaz, M.D. for measurement of the prostate volume on CT scan as well as Irfan Cicin, M.D., Nazim Can Demircen, M.D., Bulent Erdogan, M.D., and Sernaz Uzunoglu, M.D. for their contribution to the preparation of the manuscript.

\section{REFERENCES}

1. Evans A, Crook T, Laws S, Gough A, Royle G, Primrose J. Analysis of somatostatin receptor subtype mRNA expression in human breast cancer. Br J Cancer. 1997;75:798803. [CrossRef]

2. Florio T. Molecular mechanisms of the antiproliferative activity of somatostatin receptors (SSTRs) in neuroendocrine tumors. Front Biosci. 2008;13:822-40. [CrossRef]

3. Sun L, H Coy D. Somatostatin and its analogs. Curr Drug Targets. 2016;17:529-37. [CrossRef]

4. Miller G, Farmery S, Woodhouse L, Primrose J. Somatostatin binding in normal and malignant human gastrointestinal mucosa. Br J Cancer. 1992;66:391-5. [CrossRef]

5. Lamberts $\mathrm{S}$. The role of somatostatin and its analogs in the diagnosis and treatment of tumors. Endocr Rev. 1991;12:450-82. [CrossRef]

6. Patel Y, Greenwood M, Panetta R, Demchyshyn L, Niznik $\mathrm{H}$, Srikant C. The somatostatin receptor family. Life Sci. 1995;57:1249-65. [CrossRef]

7. Hofland LJ, Liu Q, Van Koetsveld PM, et al. Immunohistochemical detection of somatostatin receptor subtypes sst1 and sst2A in human somatostatin receptor positive tumors. J Clin Endocrinol Metab. 1999;84:775-80. [CrossRef]

8. Cariaga-Martinez AE, Lorenzati MA, Riera MA, et al. Tumoral prostate shows different expression pattern of somatostatin receptor

2 (SSTR2) and phosphotyrosine phosphatase SHP-1 (PTPN6) according to tumor progression. Adv Urol. 2009:723831. [CrossRef]

9. Pedraza-Arévalo S, Hormaechea-Agulla D, GómezGómez E, et al. Somatostatin receptor subtype 1 as a potential diagnostic marker and therapeutic target in prostate cancer. Prostate. 2017;77:1499-511. [CrossRef]

10. Kalkner KM, Acosta S, Thorsson O, et al. Octreotide scintigraphy and Chromogranin A do not predict clinical response in patients with octreotide acetate-treated hormone-refractory prostate cancer. Prostate Cancer 
Prostatic Dis. 2006;9:92-8. [CrossRef]

11. Hoffelt SC, Marshall LM, Garzotto M, Hung A, Holland J, Beer TM. A comparison of CT scan to transrectal ultrasound-measured prostate volume in untreated prostate cancer. Int J Radiat Oncol Biol Phys. 2003;57:29-32. [CrossRef]

12. Feldman BJ, Feldman D. The development of androgenindependent prostate cancer. Nat Rev Cancer. 2001;1:3445. [CrossRef]

13. Reubi JC, Waser B, Schaer JC, Markwalder R. Somatostatin receptors in human prostate and prostate cancer. J Clin Endocrinol Metab. 1995;80:2806-14. [CrossRef]

14. Patel YC. Somatostatin and its receptor family. Front Neuroendocrinol. 1999;20:157-98. [CrossRef]

15. Hansson J, Bjartell A, Gadaleanu V, Dizeyi N, Abrahamsson PA. Expression of somatostatin receptor subtypes 2 and 4 in human benign prostatic hyperplasia and prostatic cancer. Prostate. 2002;53:50-9. [CrossRef]

16. Chan LY, Craik DJ, Daly NL. Dual-targeting anti-angiogenic cyclic peptides as potential drug leads for cancer therapy. Sci Rep. 2016;6:35347. [CrossRef]

17. Kim HS, Shaib WL, Zhang C, et al. Phase $1 \mathrm{~b}$ study of pasireotide, everolimus, and selective internal radioembolization therapy for unresectable neuroendocrine tumors with hepatic metastases. Cancer. 2018;124:1992-2000. [CrossRef]
18. Yamamoto A, Hashimoto Y, Kohri K, et al. Cyclin E as a coactivator of the androgen receptor. J Cell Biol. 2000;150:873-80. [CrossRef]

19. Pagès $P$, Benali $N$, Saint-Laurent $N$, et al. sst2 somatostatin receptor mediates cell cycle arrest and induction of p27(Kip1). Evidence for the role of SHP-1. J Biol Chem. 1999;274:15186-93. [CrossRef]

20. Medina DL, Toro MJ, Santisteban P. Somatostatin interferes with thyrotropin-induced G1-S transition mediated by CAMP-dependent protein kinase and phosphatidylinositol 3-kinase. Involvement of RhoA and cyclin E x cyclin-dependent kinase 2 complexes. J Biol Chem. 2000;275:15549-56. [CrossRef]

21. Oesterling JE. Benign prostatic hyperplasia: a review of its histogenesis and natural history. Prostate Suppl. 1996;6:67-73. [CrossRef]

22. Giovannucci E, Rimm EB, Chute CG, et al. Obesity and benign prostatic hyperplasia. Am J Epidemiol. 1994;140:989-1002. [CrossRef]

23. Aarnink RG, de la Rosette JJ, Huynen AL, Giesen RJ, Debruyne FM, Wijkstra $\mathrm{H}$. Standardized assessment to enhance the diagnostic value of prostate volume; Part I: Morphometry in patients with lower urinary tract symptoms. Prostate. 1996;29:317-26. [CrossRef] 